\title{
Amadeus
}

International Multidisciplinary Journal IISSN 2525-8281

\section{Social Psychiatry and the demand for Mental Health Services: Some caution is valid?}

Izadora de Sousa Pereira ${ }^{1}$; Amanda Plácido da Silva Macêdo ${ }^{l}$ Ivna Celli Assunção de Sál; Larissa Melo Moreiral. Modesto Leite Rolim Neto

\begin{abstract}
Mental health in the interface with social psychiatryis a constantly evolving field. Psychiatry faces major challenges. The therapeutic relationship remains paramount. Methods: A Short Communication that focus the informational spaces of professional interests, many new ideas and concepts what are issued under the banner of "social psychiatry.". Include: discovery or development of new information's, novelty in modeling scientific and channels of information. Results: The evidences emphasize that Mental illness and interventions in psychiatry should be considered in the of social context where patients live and factors they face on a daily basis. There's a need for greater numbers of psychiatrists. Limitations: As Short Communications are expected to have higher than average impact on the field rather than report on incremental research, they will receive prioritized and rapid publication. Conclusion: Social values and concepts have played a central role in the history of mental health care, allowing more focus on possible environmental causes or factors.
\end{abstract}

Keywords: Social Psychiatryis; Mental Health; Therapeutic Relationship.

\footnotetext{
${ }^{1}$ Faculty of Medicine, Federal University of Cariri (UFCA), Ceará, Brazil. Corresponding author: modestorolim@yahoo.com.br.
} 


\section{Psiquiatria Social e a demanda de Serviços de Saúde Mental: Algum Cuidado é Válido?}

\begin{abstract}
Resumo: A saúde mental na interface com a psiquiatria social é um campo em constante evolução. A psiquiatria enfrenta grandes desafios. A relação terapêutica permanece primordial. Métodos: Uma comunicação curta que focaliza os espaços informacionais de interesses profissionais, muitas novas idéias e conceitos emitidos sob a bandeira da "psiquiatria social". Incluir: descoberta ou desenvolvimento de novas informações, novidade na modelagem científica e canais de informação. Resultados: As evidências enfatizam que doenças mentais e intervenções em psiquiatria devem ser consideradas no contexto social em que os pacientes vivem e os fatores que enfrentam diariamente. É necessário um número maior de psiquiatras. Limitações: Como é esperado que as comunicações curtas tenham um impacto acima da média no campo, em vez de reportar pesquisas incrementais, elas receberão uma publicação priorizada e rápida. Conclusão: Os valores e conceitos sociais têm desempenhado um papel central na história dos cuidados em saúde mental, permitindo maior foco em possíveis causas ou fatores ambientais.
\end{abstract}

Palavras-chave: Psiquiatria Social; Saúde mental; Relação Terapêutica.

\section{Introduction}

Mental health is inexorably linked to socio-economic circumstance. That this is happening against a backdrop of buckling mental health budgets is a lesson in how economic and social disadvantage works: while austerity measures and uncertain conditions push more people into mental health crisis, disappearing community mental health teams, staff shortages and growing waiting lists mean there are fewer and fewer places they can turn to for help (The Guardian, 2019).

Social values and concepts have played a central role in the history of mental health care. They have driven major reforms and guided the development of various treatment models (Domenico et al. 2016). A focus on the social perspective would emphasise the role of psychiatrists as agents in a social context. This requires a focus on skills and not just on knowledge. These skills may be related to, but are not identical with, what is required in conventional psychotherapeutic settings. They include an ability to use personal strengths in communicating with people with different mental disorders and influencing groups. We believe that such a focus in training and practice has a potential to strengthen 
our identity, give psychiatrists more societal relevance and make psychiatry more attractive as a profession (Priebe, Burns and Craig, 2013)

In this context, mental health in the interface with social psychiatryis a constantly evolving field, and clearly we are a long way from knowing everything. Allowing more focus on possible environmental causes or factors, instead of the over-emphasised biological ones, may allow a greater awareness of how to prevent the onset of disorders in the first place and reduce the prevalence of mental health problems generally. It may also reduce individuals thinking that 'they are the problem', as an emphasis would be placed on their environment and upbringing, rather than just on them (National Elf Service, 2017). While increased funding to cash-starved mental health services should be a priority, it will amount to little more than a particularly expensive sticking plaster unless ministers address their role in the conditions driving up the need: be it a pernicious benefit system, hostile immigrations rules, or insecure housing conditions. If not, the result will be a populace whose levels of anxiety, depression and worry will only continue to grow - which right now is the one constant in these unstable political times. (The Guardian, 2019).

Psychiatry faces major challenges. The therapeutic relationship remains paramount, and psychiatrists will need to acquire the necessary communication skills and cultural awareness to work optimally as patient demographics change. Psychiatrists must work with key stakeholders, including policy makers and patients, to help to plan and deliver the best services possible. The contract between psychiatry and society needs to be reviewed and renegotiated on a regular basis. Mental health law should be reformed on the basis of evidence and the rights of the individual. Psychiatry should embrace the possibilities offered by digital technology, and take an active role in ensuring research and care delivery in this area is ethically sound and evidence based. Psychiatry training must reflect these multiple pressures and demands by focusing on lifelong learning rather than simply knowledge delivery (Bhugra et al. 2017)

The evidence reinforces the idea of community social capital, with caregivers and professionals playing a leading role. Yet, the cost of collective action is mainly supported by individuals with a mental condition - which unveils their vulnerability (Cigarini et al. 2018). Possibilities of learning should be opened up before skills are honed to suit specific scenarios. These artists provoke questions. Who has control of our bodies? Who is allowed to do what to whom? These questions are highly charged; they are of concern 
to patients, to policy-makers, and to hospital ethics committees and therefore important to medical students and the context in which they can act (Willson, 2006).

The range of potential targets for social interventions is dauntingly wide and extends far beyond mental health services, encompassing individual, family, community and societal levels. Although there are few well-specified and evidence-based interventions that meet criteria for guideline inclusion, forms of help focused on the social have long been offered in many settings (Johnson, 2017).

The shifting sands of professional interests, many new ideas and concepts are issued under the banner of "social psychiatry." Despite the conjunction of the traditional opposites (socius and psyche), the term has become accepted through usage. It appears in the names of institutes, professorships, learned journals, and numerous books; a few people even identify themselves as "social psychiatrists." Such widespread usage suggests that a special field has come into existence, one that needs distinguishing from clinical psychiatry by the addition of the adjective "social" and from social psychology (or sociology) by the inclusion of "psychiatry" (Bell \& Spiegel,2018) .

Human beings are social animals, and familial or social relationships can cause a variety of difficulties as well as providing support in our social functioning. The traditional way of looking at mental illness has focused on abnormal thoughts, actions and behaviours in response to internal causes (such as biological factors) as well as external ones such as social determinants and social stressors. We contend that psychiatry is social. Mental illness and interventions in psychiatry should be considered in the framework of social context where patients live and factors they face on a daily basis (Ventriglio, Gupta and Bhugra, 2016).

With the drive to transform mental health services and treat more patients, there's a need for greater numbers of psychiatrists. Mental health problems such as depression affect one in four adults and their only hope may be a talking therapy or a prescription for antidepressants (The Guardian, 2018a).

If we felt more comfortable about mental health and saw it unapologetically as another health issue then psychiatry would take a huge step forward. Work is needed to address the inequalities that people with mental health problems and learning disabilities encounter daily in terms of their health, life chances and inclusion. We will achieve this not by throwing out the recovery model, but because of it (The Guardian, 2018b). 
There is a longstanding reluctance in some quarters to acknowledge the relationship between politics and mental health. Some caution is valid: the reasons behind mental health conditions are varied and complex and it's right that specialists like the Samaritans stress suicidal feelings in particular should not be put down to a single cause. But there is also a sniffy denialism at work - the idea that we shouldn't get "political" about such subjects, as if poverty or power weren't related to the decisions of politicians; or the belief that insecurity, fear and hardship are inevitable for certain sections of society (The Guardian, 2019)

\section{Highlights}

Social values and concepts have played a central role in the history of mental health care.

Mental health in the interface with social psychiatryis a constantly evolving field, and clearly we are a long way from knowing everything.

The therapeutic relationship remains paramount, and psychiatrists will need to acquire the necessary communication skills and cultural awareness to work optimally as patient demographics change.

The shifting sands of professional interests, many new ideas and concepts are issued under the banner of "social psychiatry." Despite the conjunction of the traditional opposites (socius and psyche), the term has become accepted through usage. It appears in the names of institutes, professorships, learned journals, and numerous books; a few people even identify themselves as "social psychiatrists."

\section{Acknowledgements}

The authors' thank Research Group: Suicidology-Federal University of Ceará UFC and National Council for Scientific and Technological Development-CNPq - body linked to the Ministry of Science, Technology and Scientific Writing Lab, Medicine School - Federal University of Cariri - UFCA 


\section{Role of the funding source}

Research Group: Suicidology-Federal University of Ceará - UFC / National Council for Scientific and Technological Development-CNPq - body linked to the Ministry of Science, Technology and Innovation to encourage research in Brazil.

\section{Conflict of interests}

The authors declare that they have no competing interests.

\section{References}

The Guardian. (2019). Austerity created this mental-health crisis. Brexit has sent it into overdrive. Retrieved from: https://www.theguardian.com/commentisfree/2019/mar/14/ austerity-mental-health-brexit

Domenico, G., et al. (2016). Scenarios for the future of mental health care: a social perspective.The Lancet Psychiatry ,4 (3):257 - 260. Retrieved from: https://www.thelancet.com/pdfs/journals/lanpsy/PIIS2215-0366(16)30219-X.pdf

Priebe, S., Burns, T., Craig, T.K.J. (2013). The future of academic psychiatry may be social. The British Journal of Psychiatry; 202: 319-320. Retrieved from: https://www.cambridge.org/core/services/aop-cambridge-core/content/view/BE1E1986 DE41E0CAA9B406E5E4CD3370/S0007125000274321a.pdf/future_of_academic_psychia try_may_be_social.pdf

National Elf Service. (2017). The future of mental health care:time for a social perspective? Retrieved from: https://www.nationalelfservice.net/commissioning/ servicereconfiguration/the-future-of-mental-health-care-time-for-a-social-perspectivel

Bhugra, D., et al. (2017). The WPA-Lancet Psychiatry Commission on the Future of Psychiatry. Lancet Psychiatry; 4: 775-818. Retrieved from: https://beta.legeforeningen.no/contentassets/cf1e873b82bf4694bdc2efc3b6980b61/thewpa-lancet-psychiatry-commission-on-the-future-of-psychiatry-2017.pdf

Cigarini,A., Vicens, J., Duch, J., Sánchez, A., Perelló, J. (2018).Quantitative account of social interactions in a mental health care ecosystem: cooperation, trust and collective action. Scientific Reports, 8: 3794 (2018) Retrieved from: https://www.nature.com/articles/s41598-018-21900-1 
Willson, S. Essay: What can the arts bring to medical training? The Lancet, 368:S15 - S16. Retrieved from: https://www.thelancet.com/pdfs/journals/lancet/PIIS0140-6736(06)699091.pdf

Johnson, S. (2017). Social interventions in mental health: a call to action. Psychiatr Epidemiol; 52(3): 245-247. Retrieved from: https://link.springer.com/ article/10.1007/s00127-017-1360-6

Bell, N., Spiegel, J.P. Social Psychiatry Vagaries of a Term.(2018). Arch Gen Psychiatry. 1966;14(4):337-345. Retrieved from: https://jamanetwork.com/ journals/jamapsychiatry/article-abstract/488993

Ventriglio,A., Gupta, S., Bhugra, D. (2016). Why do we need a social psychiatry?. The British Journal of Psychiatry; 20: 1-2. Retrieved from: https://www.cambridge.org/core/services/aop-cambridge-core/content/view/43B885185 BE66FC156CED7E98B08CB84/S0007125000244231a.pdf/why_do_we_need_a_social_p sychiatry.pdf

The Guardian. (2018a). Psychiatry - the medical speciality that combines empathy and science. Retrieved from: https://www.theguardian.com/royal-college-of-psychiatristscourses/2018/jun/05/psychiatry-the-medical-speciality-that-combines-empathy-and-science

The Guardian. (2018b). What psychiatry is really for - The proposed new NHS consititution offers the opportunity to remodel mental health services. Retrieved from: https://www.theguardian.com/society/joepublic/2008/jul/09/whatpsychiatryisreallyfor.

\section{How to cite this article (APA format):}

Pereira, Izadora de Sousa; Macêdo, Amanda Plácido da Silva; Sá, Ivna Celli Assunção de; Moreira, Larissa Melo; Rolim Neto, Modesto Leite. (2019). Social Psychiatry and the demand for Mental Health Services: Some caution is valid? Am. In. Mult. J., October a December. (7) 4, 196-202.

Received: $11 / 25 / 2019$

Accepted: 12/04/2019 